\title{
A Pragmatic Study of "The Lahore Attack" by Sri Lankan Cricketer Kumar Sangakkara: A Parody of Sportsmanship under Servile Diplomacy
}

\author{
Dr. Edirisingha Arachchige Gamini Fonseka \\ Professor, Department of English \& Linguistics, University of Ruhua, Sri Lanka \\ drgamini@gmail.com
}

\begin{abstract}
As the cricketer of British origin, Michael Colin Cowdrey,is unanimously appreciated as a role model in cricket, being invited to Lord's to deliver the annual MCC Cowdrey Memorial Lecture is considered by many cricket aficionados an honour bestowed not only on the speaker himself but also the country he represents. Before Kumar Sangakkara, world renowned cricketers such as Martin Crowe from Australia, Sunil Gavaskar from India, and Imran Khan from Pakistan had been called upon to perform this task (www.lord's). Thus, when Sangakkara received an invitation to deliver MCC Cowdrey Memorial Lecture in 2011 at Lords, he represented not only himself but also Sri Lanka, his homeland. While others in general strive to preserve the respect of their homelands in front of international audiences at such places, Sangakkara not only alienates himself from his community but also is unduly critical of the cricket in his homeland. His behaviour well-formulated to suit the practice of servile diplomacy - the hallmark for the opportunistic many that travel abroad from Sri Lanka, signifies a parody of sportsmanship. Whatever Sangakkara said in his speech is immaterial to the intellectual and professional community of Sri Lanka, but it causes concern as it has been unfortunately included in the 2015 GCE (O' Level) syllabus for Appreciation of English Literary Texts prescribed by the Ministry of Education, Sri Lanka. Therefore this paper on the whole pragmatically analyses the interpersonal rhetoric in the text of his speech in an investigation into the implications of including it in a national curriculum that is meant to ensure a healthy linguistic and attitudinal development in the user.
\end{abstract}

\section{Interpersonal Rhetoric In PERCEIVING Implicatures in A PUBLiC SPEECH}

As it is noticed that, throughout his speech, Sangakkara violates most of the fundamental conditions of discourse, it invites a pragmatic analysis of the illocutionary functions he carries out there. In order to examine the sense and force of the illocutionary functions a speaker carries out, in an approach to interpersonal rhetoric, H.P. Grice (1975) provides a set of maxims under his Cooperative Principle. As Snježana Kordić (1991), explains, the cooperative principle can be divided into four categories of maxims - quantity, quality, relation, and manner - that describe specific rational principles observed by people who obey conditions of effective communication. Grice (1975) proposed these conversational maxims as those arising from the pragmatics of natural language.

Grice's Maxims

Maxims of Quantity:

1. "Make your contribution as informative as required."

2. "Don't make your contribution more informative than is required."

Maxims of Quality: Be truthful.

1. "Don't say what you believe to be false."

2. "Don't say what you lack adequate evidence for."

www.arjonline.org 

Sportsmanship under Servile Diplomacy

Maxim of Relation: "Be relevant."

Maxims of Manner: "Be perspicuous."

1. "Avoid obscurity of expression."

2. "Avoid ambiguity."

3. "Be brief (avoid unnecessary prolixity)."

4. "Be orderly".

(Grice 2004)

Applying the Gricean Maxims is a way to explain the link between utterances and what is understood by them. Because of the poor quality of the language and the numerous pragmatic weaknesses it contains, it was thought earlier that the speech had been made impromptu. But the video in Youtube makes it evident that it was read out from a text. A speech of that sort could have been carefully documented by observing general ethics of discourse to satisfy the maxims of quantity, quality, relation, and manner. Yet, as it is understood, in a selfstyled personal mission focused on self-aggrandizement, Sangakkara's main target has been to win personal sympathy from the audience at the expense of his homeland, the nation he represents, and the members of his team. This is why he appears like a farcical hero who parodies sportsmanship, calling himself "an unofficial ambassador for Sri Lanka", while engaged in a mission of servile diplomacy.

\section{Complacency about Life IN THE FEAR-STRICKEN Colombo}

At the onset of this section of his long speech "The Lahore Attack", Sangakkara considers that he used to be fortunate not to have experienced violence in Sri Lanka "first hand". He also implies that, before his experience of violence in Lahore, he had just heard of the "many bomb explosions" triggered off in various places in Sri Lanka "over the years". In order to establish his claim on his being fortunate regarding his distance from incidents of violence, he declares, "I was never in the wrong place at the wrong time." (Sangakkara 2011) The cliché he uses here betrays a lack of wit as well as a lack of empathy on the part of Sangakkara because he sounds as if he believed that those bomb victims had wished to be "in the wrong place at the wrong time". These types of expressions he uses throughout his speech to highlight his 'fortunate' status as a scion of the upper middleclass raise numerous queries. Do all people who get caught in a bomb explosion, consciously go to its venue? How many of his fans might have been killed in such brutal bomb explosions? Where is his sensitivity? Hackneyed phrases such as these reflect negatively on the personality of the speaker. It is surprising to notice that he has not at least visited a hospital to see the victims admitted, nor did he attend the funerals of any who died. One cannot predict what happens where terrorism is concerned. In fact a paradox develops from this declaration as it implies that, a veteran cricketer with an elite lifestyle, Sangakkara had nothing to do with the struggles of his adoring fans, the ordinary people who were always exposed to violence. Are cricketers just lotus-eaters?

"In Colombo, apart from these occasional bombs, life was relatively normal. People had the luxury of being physically detached from the war. Children went to school, people went to work, I played my cricket" (Sangakkara 2011)

As in cricket, Sangakkara plays extremely safe with his words on the situation of Colombo, the capital of Sri Lanka where Sangakkara resides in a villa in Perera Gardens at Pelawatte. Like most of the politicians of Sri Lanka, he sounds submissive to his audience. In the phrase "apart from these occasional bombs" that refers to the security condition of Sri Lanka, he sounds quite casual or light-hearted about the danger the people used to live with, before terrorism was defeated by the Sri Lankan armed forces on May $09^{\text {th }}, 2009$. In the claim, "life was relatively normal..." he sounds not to have any notion of what the average citizen was undergoing. 

Sportsmanship under Servile Diplomacy

His insensitivity to the grievances of the ordinary people of Sri Lanka is clear in the reckless generalization he makes out of the phrase "the luxury of being physically detached from the war", which may have been true for him but not the average citizen of Colombo. He treats the terrorist attacks as another form of cricket. Of course, it is true that not only the players but also those who are cricket fanatics remain detached from the socioeconomic and political realities of their country. They watch while the players carry on with the batting, balling and fielding. His description of how the days were spent with people going to work, children going to school, and him playing cricket, projects his ignorance of the terrible realities the ordinary people were faced with. Consequently, in these lines, Sangakkara represents a selfish and self-important alienated fraction of the Sri Lanka elite that always spoke softly about terrorism. Regarding interpersonal rhetoric a conclusion can be drawn here that Sangakkara violates the maxim of quality by pretending not to know about violence that prevailed for over thirty years in Sri Lanka.

\section{INDIFFERENCE TO TERRORISM IN SRI LANKA}

His aloofness from the struggles of the ordinary people of Sri Lanka becomes explicitly clear in his reference to violence in the other parts of the island. He talks about the armed forces fighting terrorism in the northern and eastern territories of Sri Lanka as a group of people engaged "in the defence of their motherland". It is intriguing to notice that, by calling Sri Lanka "their motherland" that means "the motherland of those soldiers", he implies not to have any sense of belonging with either the soldiers or Sri Lanka. Could it be a Freudian slip, an inadvertent mistake in speech or writing that is thought to reveal a person's unconscious motives, wishes or attitudes? (dictionary.com) What he means by "geographical circumstances" the inhabitants in the war zone were struggling with is obviously ambiguous. Sri Lanka did not have volcanoes, earthquakes, or annual tsunamis for the inhabitants of those war-torn areas to survive, and except poverty, the only problem they had was the LTTE terrorism. By sounding ambiguous he violates the maxim of quality. Moreover, Sangakkara refers to "bullets, shells, mines and grenades" as if some things falling from heaven, but does not mention the terrorists who attack the innocents with them. His emphasis on "avoiding" them "for survival" fits the cricket ground but not the actualities the people were faced with. How can the unarmed people avoid bullets, shells, mines and grenades, when the terrorists kill them in their sleep? On the whole he flouts the maxim of quantity by trying to maintain a distance from the community of Sri Lanka. In the context they are used, his "sympathy" and "compassion" remain mere words empty of spirit. Sounding ignorant, inarticulate, inexperienced and dispassionate about the circumstances of violence in Sri Lanka, he safely moves onto the Lahore scenario in Pakistan.

\section{BORED AFTER THE FIRST TEST IN KARACHI}

Sangakkara reveals in the four paragraphs just before the actual report on the attack, the mood of the Sri Lankan cricket team that toured Pakistan in 2009 to play two Tests in Karachi and Lahore.

A test match in cricket is generally played over five days, with three sessions of two hours interspersed with a 40-minute break for lunch and 20-minute break for afternoon tea per day. (www.abcofcricket.com)

So the arduousness of the tour is perceivable. Generally, in March, Karachi is extremely hot, and one can imagine what a painful time it should have been for the team. He talks about playing the first Test on a "featherbed", meaning that the ground they played on was supposed to be "a pitch which is considered to be good for batting on, offering little, if any, help for a bowler"(www.cricker.com). Like Sri Lanka used to be before May 2009, Pakistan has always had a reputation for incidents of violence because of the Muslim Fundamentalist terrorist groups. However, according to Sangakkara, except for the problem with the pitch, there was no disturbance to interrupt the playing.

"The second Test was also meandering along with us piling up a big first innings when we departed for the ground on day three" (Sangakkara 2011). 

Sportsmanship under Servile Diplomacy

Here Sangakkara uses a "stream" metaphor to indicate the boredom the team was suffering from in the course of the Second Test. The past continuous form of the verb "meander" effectively conveys how slowly the time allocated for the Second Test was being spent like a stream "following a winding and turning course" (MarianWebster) that reflects on the team "moving aimlessly and idly without fixed direction" (Marian-Webster).

Sangakkara's statement about the team "piling up a big first inning" implies that the team was playing well, keeping an impressive run rate. Yet, by the time they have come to their third day in the Second Test, the players seem to be feeling terribly bored. During their journey to the grounds, they are "anticipating a day of hard toil for the bowlers." So it is clear that the team was heading for a bowling session after a successful batting session over the previous two days and it is natural for the team to feel nonchalant about themselves facing the challenge ahead. Their fight was only to preserve their run rate.

\section{PRAYing FOR A BOMB EXPLOSION}

Sangakkara highlights fast bowler Thilan Thushara's vociferous complaint about his acute back pain that had given him the feeling that his back was at the point of breaking.

"He joked that he wished a bomb would go off so we could all leave Lahore and go back home" (Sangakkara 2011)

Even though a joke of that sort was actually there in the bus, it is only out of irresponsible garrulousness one can mention such a thing in a public talk before a foreign audience. Sangakkara seems to be in the habit of washing dirty linen in public. There is no harm if he mentions it at a chat in a coffee shop, but in a solemn address, it reflects not only on the poor fast bowler Thilan Thushara, but also the entire community of Sri Lanka (at large). Consciously or not, Sangakkara exposes Thilan Thushara's tendency to be evasive in front of challenges. Calling himself "an unofficial ambassador for Sri Lanka", he gets the other communities to laugh at his team as well as Sri Lanka by divulging such small talk taking place privately during a bus journey. He violates the maxims of quantity, quantity, manner and relation by presenting unnecessary but obnoxious information. His lotus-eater attitude that has prevented him from sensing the gravity of the circumstances of violence in Sri Lanka recurs in this.

Of course the audience must have laughed their heads off and Sangakkara, the blunt, must have been elated that he had cracked a witty joke to cheer up his listeners, but there might have been at least one or two who would have thought of the insensitivity of the species called cricketers. What is a bomb explosion? Is it a decorative pyrogenic display? Does it not destroy life? Does it not damage public and private property? Does it not threaten the lifestyle of the town where it goes off? How can one talk so lightly about bombs? How can one think about enjoying an early homeward journey at the expense of the other people's lives? If it is not the speaker's intention, it should not be mentioned in a solemn oration in a foreign land. His lack of pragmatics is disgraceful.

\section{EXPERIENCING ViOLENCE FirSTHAND}

The Time reports the actual incident of the attack on the Sri Lankan cricket team that Sangakkara relates in the following terms:

"In a commando-style operation, a dozen gunmen attacked the Sri Lankan cricket team in the heart of Lahore, Pakistan's cultural and political hub, at 8:45 Tuesday morning. The attackers fired rockets, grenades and multiple rounds of ammunition at the team's bus and the police escorting it, killing eight people and injuring six ...

"The gunmen killed five policemen, two bystanders and the bus driver. Six members of the Sri Lankan cricket team were injured. Two of the cricketers were shot, while others sustained minor injuries from flying debris. The reserve umpire for the ongoing test match, Ahsan Raza, a Pakistani, is in critical condition. "It was horrifying," Nadeem Ghouri, the Pakistani umpire, told Reuters. "There were bullets flying around 
us and we didn't know what was happening. When the firing started, we all went down on the floor of the coach. Our driver was killed instantly from a shot from the front" (Omar Waraich 2009).

The report makes it clear that it was "a commando-style operation" where the attackers "fired rockets, grenades and multiple rounds of ammunition" and killed "eight people and injuring six".

\section{LACK OF LEADERSHIP AND DECISION-MAKING IN CRISES}

When the terrorists started firing, somebody shouts, "Get down, they are shooting at the bus." To that command, "Everyone dived for cover and took shelter on the aisle or behind the seats." Sangakkara compares the fire of "rockets, grenades and multiple rounds of ammunition" to a "rain on a tin roof". Maybe his cocooned lifestyle described above has prevented him from coining a more suitable metaphor to convey the severity of the shower of bullets on the tin roof of the bus. The obscurity and prolixity effected thus by inappropriate metaphor violates the maxim of quality. "The bus was at a standstill, an easy target for the gunmen." One may question whether the gunmen hit the tires or the engine? But there is no report as such. So the absence of leadership is clear in the groping for a proper decision at this moment of emergency.

As bullets started bursting through the bus all we could do was stay still and quiet, hoping and praying to avoid death or injury. (Sangakkara 2011)

This suggests how the selfish and smug that have no concern for the ordinary people's worries and agonies are repaid. They have no opportunity to cultivate resistance in the presence of violence as they deliberately turn a blind eye on the issues of terrorism which affect the ordinary people in the first place. So it is a question of how advisable it is to accommodate claims made by such "unofficial ambassadors for Sri Lanka".

\section{LAMENTING INJURIES SUSTAINED BY INDIVIDUAL CRICKETERS}

The report on the situation on board the bus at the moment of bombing is given in the present tense as if a piece of compeering from a cricket tournament. It is indeed appropriate for the dramatization of what went on inside the bus with numerous lamentations and complaints. Sangakkara starts with Captain Mahela Jayawardene who complains from "the back of the bus" that he "has been hit in the shin". Then he moves on to Thilan Samaraweera, who "groans in pain as a bullet ... [has hit] him in the back of his thigh". The ever fortunate Sangakkara claims to have had a narrow escape from a bullet that pierced "the side of the seat" where he had rested his "head" a few seconds before but is benumbed by another bullet that hit him in the "shoulder".

His treatment of Tharanga Paranvithana who is now "unconscious" with a "blood-soaked chest" is far from being appropriate. He turns Paranavithana's "debut tour" into a grand joke. "Oh my God, you were out first ball, run out the next innings and now you have been shot." This interjection with a description of three miserable events aligned in such a way that it leads to a sad climax is full of tragic suspense. "What a terrible first tour." By portraying the unfortunate destiny of the most seriously injured member of the team in a theatrical tone, he flouts the maxim of relation.

"It is strange how clear your thinking is. I did not see my life flash by. There was no insane panic. There was absolute clarity and awareness of what was happening at that moment" (Sangakkara 2015)

These words on his clear mental disposition, consciousness and sanity prove just empty words as he remains there only "hoping and praying to avoid death or injury" but without action or coming up with any way-out from the deadly situation. Here he violates the maxims of quality, relation, and manner by contradicting his previous claims of cowardice. Yet those words apply sharply to Tilakaratne Dilshan who keeps "screaming at the driver, 'Drive...Drive'" and gets the bus started and driven to the stadium. While the Captain and the Vice Captain both dwell on their hopes and prayers, this team member, who has no specific role to play, gets the bus driven until they are inside "the stadium." Therefore the hero of the moment should be Tilakaratne Dilshan. 


\section{LOOKING BACK IN Comic Humour}

When the bus is away from the danger zone it is understandable that everybody is anxious to get up from their uncomfortable position and get back to their normal behaviour. As Sangakkara reports, it is natural that "There is a rush to get off the bus." In trying to explain the condition of Paranavithana, who was "still bleeding" with "a bullet lodged lightly in his sternum" probably as reported by a surgeon, Sangakkara makes a hilarious confusion in the sequence of the incidents - the movement of the bus and the patient's condition as discovered after diagnosis. The idiom in the phrase "the body of the bus tempering its velocity enough to be stopped by the bone" is ambiguous and the entire thing sounds nonsensical. It is not clear whose "bone" he is talking about. Do buses have bones? Only God knows. "We again get back to the bus regarding Thilan Samaraweera, who is being helped off." The atmosphere of the dressing room with "a mixture of emotions" where "players and coaching staff are being examined by paramedics" presents an authentic picture of the situation. "Thilan and Paranavithana are taken by ambulance to the hospital." There is an element of inappropriateness in the alignment of collocations in the sentence though it conveys the idea. The obscurity that emerges from the syntax and the metaphor violates the maxim of manner. However, Sangakkara manages to narrate how the tension inside the dressing room subsides and the atmosphere is lightened by laughter and jocundity.

\section{CONFESSION TO A NEW OUTLOOK ABOUT Victims OF TERRORISM}

"We have for the first time been a target of violence." Until such time he, as mentioned earlier, sounds not to have bothered about the loss of life or damage to property caused by terrorist attacks in his homeland.

What Paster Martin Niemöller (1941) suggests in his poem regarding the Nazis becomes true to him in his helplessness, when terrorists knock at his door or stifle him with the horror of gunfire.

"Then they came for the me

And there was no one left

To speak for me" (Niemöller 1941).

He conveys his response to the experience of horror in the following terms: "We all realized that what some of our fellow Sri Lankans experienced every day for nearly 30 years. There was a new respect and awe for their courage and selflessness" (Sangakkara 2011). In fact, in these terms, Sangakkara makes a very naïve schoolboytype confession to changing his view about the plight of the ordinary people of Sri Lanka living amidst the horrors of terrorism. He sounds, as if he has just come out of his cocoon to have a glance at the world. The total section is irrelevant in the real sense and violates the maxim of quality. However, this indirectly emits a message to all who defend terrorism for various types of opportunistic gains such as political power, popularity, financial benefits, migration to green pastures, or career prospects.

\section{BACK TO NORMAL IN THE ABSENCE OF TERRoR}

Sangakkara demonstrates an element of childishness in his boasting of the quick recovery the team made from the nightmare they had a few hours before. "It is notable how quickly we got over that attack on us. Although we were physically injured, mentally we held strong" (Sangakkara 2011). Who should take note of their quick recovery? He seems not to have been to an accident ward of any hospital in Colombo or elsewhere to notice the mood and behaviour of the patients with serious injuries. One sustains an injury but does not keep howling although the pain does not leave at once unless there is a particular reason. According to his report, only two of them sustained serious injuries. If the minor injuries the other cricketers sustained were dressed and they are given an assurance as to that their lives are no more in danger, they have no reason to feel so helpless. Sangakkra flouts the maxim of quality by an unsuccessful attempt to draw sympathy through self-praise. They can jollywell be contented that they are in safe hands. It is hard to feel pity for Sangakkara whose pampered attitude 

Sportsmanship under Servile Diplomacy

that makes his behaviour pathetic here. This reminds one of what Australian Captain Shane Warne heard from Sri Lanka's Foreign Minister Lakshman Kadiragamar when he refused to play in Colombo after World Cup 1996. When Warne complained about bombs that would probably go off in the middle of his shopping, Kadiragamar hit back saying, "Shopping is for Sissies" (Clementine 2011). Likewise, crying like kiddies is not for sportsmen, and not even for Sissies.

\section{TAlis of Heroism While in a High SeCurity Zone}

Airlifted to the Lahore Air Force Base, Sangakkara and his fellow cricketers are currently in a high security zone. Feeling safe in a high security zone, any coward may behave as if in high spirits. How the look of Ajantha Mendis with "his head swathed in bandages after multiple shrapnel wounds" suggests to Sangakkara "a game of Poker" is not clear. Poker is "a card game in which players attempt to acquire a winning combination of cards and bet at every deal" (Encarta Dictionary). Maybe he is referring to a poker player hit on the head in a fight during a game of poker. The ambiguity suggests violation of the maxim of manner. His cheerfulness towards Thilan Samaraweera "sedated but fully conscious" at present is commendable as every patient needs a little fun for early recovery. Yet his boastfulness betrays his hypocrisy, contradicting what he expressed earlier.

"We were shot at, grenades were thrown at us, we were injured and yet we were not cowed. We were not down and out.

"We are Sri Lankan," we thought to ourselves, "and we are tough and we will get through hardship and we will overcome because our spirit is strong"(Sangakkara 2011).

These words, maybe uttered with Dutch courage, suggest just a façade of heroism assumed in front of the media people and the VIPs who visited the injured cricketers in the high security zone. The fakeness of the gallantry and manliness attempted at through these expressions is exposed by the psychological surrender he made in the bus only a few hours ago and the indifference he maintained regarding the fighting in Sri Lanka against terrorism. Out of fear he did not even show any sense of belonging towards Sri Lanka and the soldiers who were fighting for her.

"As bullets started bursting through the bus all we could do was stay still and quiet, hoping and praying to avoid death or injury" (Sangakkara 2011).

Aloof of the struggles of the other people, he was unprepared and therefore was unable to do anything constructive in that deadly crisis.

Expressions of cowardice, indifference, and bravery come together in a potpourri without giving any notion of his true personality. This suits his claim about his identity made elsewhere in the same lecture: "I am Tamil, Sinhalese, Muslim and Burgher. I am a Buddhist, a Hindu, a follower of Islam and Christianity. I am today, and always, proudly Sri Lankan." Can somebody practically be so? What evidence does he have to establish his claim? In order to emphasize one's tolerance of other ethnicities, one does not need to claim that one belongs to all of them. Sangakkara might have thought that his audience would applaud everything he utters because of the fame he has achieved in the cricket ground. Of course anybody would respect his performance in cricket, but that does not mean that the others have to accept all that he says as holy writ. Moreover, he childishly advertises the so called "calm, collected, and rational" behaviour the team maintained throughout the ordeal by referring to the "interviews" they gave "immediately after the attack". Sangakkara is unsuccessful at masking his egoism when he says, "Our emotions held true to our role as unofficial ambassadors." The really valiant do not boast of their fortitude. The speech acts he commits here violate the maxims of quality, quantity, relation and manner. While applying the term "unofficial ambassador" to himself, he shows indifferenceto his motherland's worries of terrorism, betrays his cowardice in the bus, and boasts about an absent heroism when his safety is guaranteed. 


\section{BACK HOME: WHO IS THE HERO?}

Sangakkara brings in a conversation he had with a soldier at a checkpoint in Colombo, just a week after his return from Pakistan, to illustrate "the passion that cricket and cricketers evoke in Sri Lankans". In the following terms, Sangakkara relates his response to the soldier's "How are you?"

"I said I was fine and added that what they as soldiers experience every day we only experienced for a few minutes, but managed to grab all the news headlines" (Sangakkara 2011).

What Sangakkara said to the soldier sounds true because, in Sri Lanka, even at the peak of terrorism, the media marketed cricket news with more profit than war news, while some politicians made demoralizing statements such as, "any bull can fight a war" (Maitipe, 2007). So Sangakkara's claim, in terms of the euphoric popularity the game has achieved, has some basis.

This can be further supported by the anecdote that the late Sir Arthur C. Clerke, the visionary scientist and intellectual of British origin, who made Sri Lanka his home, "once privately joked how easy it would be to stage a coup in Sri Lanka on the night of a cricket final" (Gunawardene, 2008). Yet there are many Sri Lankans who look at what is called "cricket fever" sarcastically. In early 1996, Clerke "told a Reuters correspondent that he shared the (minority) view that cricket was the slowest form of animal life: test cricket in particular can drag on for days and yet end up without a result" (Gunawardene, 2008). Some people claim that cricket has evolved into a monster that spreads intellectual poverty all over the country.

The soldier's next exchange is full of politeness.

"It is OK if I die because it is my job and I am ready for it. But you are a hero and if you were to die it would be a great loss for our country" (Sangakkara 2011).

Sangakkara seems to have been extremely lucky to have met the particular soldier. While many soldiers joined the Sri Lanka Army just to safeguard their motherland from terrorism, this one thinks exactly to the advantage of Sangakkara's effort to promote cricket and cricketers. He seems to be doing "a job ending in death". Again the maxims of quality, quantity, relation and manner are violated in a naïve effort to become a hero. This naïve soldier seemed not to have heard of any hero in the calibre of Corporal Gamini Kularatne of Hasalaka who sacrificed his life in 1991, to protect his camp at Elephant Pass from an advancing LTTE bulldozer tank filled with ammunition. (See VVIP.LK, 2014) Sangakkara, though claims to have been "taken aback" and "felt humbled", simplistically clings on to the literal meaning of what the soldier said and confirms it as a statement made for him out of "overwhelming" "sincerity". He makes a reckless generalization on a casual statement from a soldier at a checkpoint. The implication of his idea to carry it to Lord's is to claim that he deserves such a compliment accorded to a hero. Also Sangakkara pretends here that he does not enjoy any financial benefit from playing cricket. Are cricketers not paid for the matches they play?

This reminds of the satire in Hemingway's (1929) Farewell to Arms on how medals are manipulated in the military, projected through the famous conversation between Frederic Henry and Rinaldi that takes place at a military hospital. While Rinaldi congratulates Henry on the prospect for him to receive a medal of heroism for his injuries, Henry claims he does not deserve such an honour, because he was injured while eating cheese. With Sangakkara one experiences the opposite. Through "the love" shown by the poor soldier at the checkpoint, Sangakkara introduces himself to the audience as a demigod to the people of Sri Lanka. He is marketing himself out of everything that he comes across in his way. Does Sri Lanka's professional community have only a bunch of cricketers? What about the other Sri Lankan professionals who have made more significant contributions to the world than cricketers? These are questions to be asked to ourselves. 


\section{CONCLUSION}

The above pragmatic study of this section from his long speech "The Lahore Attack" reveals how Sangakkara undermines his own dignity as well as that of his homeland in front of a predominantly British audience cynical about Sri Lanka's defeat of terrorism, despite reiterated warnings made by the then British Foreign Minister David Miliban. (See The Telegraph 29.04.2009) The simplistic and evasive attitude he maintains during his entire speech looks to be part and parcel of his character because, as according to his own words, his behaviour during the Lahore attack screams of timidity and lack of strategy. The very handicap that has prevented him from empathizing with socio-political issues at home seems to have prevented him from making the right decision at this crisis where his decision making prowess was crucial to the survival of the entire team. However, (later) at the high security zone at Lahore Air Force Base, he manages to give interviews of gallantry to the media and visitors. Finally, back home in Sri Lanka, capitalizing on a casual statement made by a soldier at a checkpoint, he claims that people in Sri Lanka adore cricketers as heroes much more enthusiastically than the soldiers fighting terrorism. While reducing the soldier's role to that of a paid worker, he deliberately conceals the fact that cricketers are paid for their participation in the tournaments. Yet the twelve-member panel responsible for the Teacher's Resource Book published by the NIE introduces the text as follows:

This is an extract from Kumar Sangakkara's Colin Cowdrey Lecture delivered on 5th of July 2011 at Lords which mesmerized the whole world, by its sincerity, dignity and patriotism. The elocutionary force of the speech comes from its sheer love and regard for his country and countrymen. It is a unique expression of responsibility as a leader, for Kumar it as a leader in cricket. He thinks that the love and regard the people of Sri Lanka have for the game of cricket and cricketers should be reciprocated by the cricketers themselves. (NIE 2015)

The writers themselves blatantly violate the Cooperative Principle propounded by Grice because of their overenthusiasm and lack of pragmatic knowledge. How do they establish that this speech "mesmerized the whole world"? Do people attend lectures to get "mesmerized" and remain in torpor to forget about their normal affairs? How many countries in the world play cricket? How do they perceive "sincerity, dignity and patriotism" in statements that ridicule his team? Is there any evidence that "the elocutionary force of the speech comes from [its] sheer love and regard for his country and countrymen"? Do all people in Sri Lanka play cricket? What is the representation the cricketers make up of the professional body of Sri Lanka? The quality of his speech was thus assessed under the framework of the Cooperative Principle that Grice developed, in terms of the maxims one follows to have a decent conversation, so that it would reveal whether it is efficacious for it to appear in a national syllabus.

Finally, Kumar Sangakkara himself should gauge the impact of his irresponsible statements on the country he represents, when he makes this type of bizarre talk in public, especially in the capacity of "an unofficial ambassador for Sri Lanka". I hope the teachers will not plague schools with this type of slipshod oratory. At the same time the National Institute of Education (NIE), the central body responsible for the primary and secondary education of Sri Lanka, should not take the schoolchildren for granted while selecting materials for inclusion in their syllabuses.

"Littlejohn and Windeatt (1989) argue that materials have a hidden curriculum that includes attitudes toward knowledge, attitudes toward teaching and learning, attitudes toward the role and relationship of the teacher and student, and values and attitudes related to gender, society, etc. Materials have an underlying instructional philosophy, approach, method, and content, including both linguistic and cultural information" (Kitao \& Kitao, 1997).

Accordingly, the task of selecting materials for a curriculum demands so much of serious thinking. The curriculum designers should not enjoy any undue liberty to impose through the curriculum their personal choices on the learners. Whatever they introduce regardless of the damage it would cause to the learners' upbringing, have grave consequences in the context of nation building. Therefore it should be seriously taken into consideration that the presence of this type obnoxious material in the syllabuses only exposes the intellectual bankruptcy of the National Institute of Education. What is required to be in a syllabus in English Prose targeted at a juvenile 
A Pragmatic Study of "The Lahore Attack" by Sri Lankan Cricketer Kumar Sangakkara: A Parody of Sportsmanship under Servile Diplomacy

audience is pedagogically powerful reading materials produced in decent language with a focus on contributing to the learners' character development by inculcating in them values that transcend personal interests.

\section{REFERENCES}

1. ABC of Cricket. "Cricket Explained - Test Match Cricket." http://www.abcofcricket.com/cfb1/cfb5/cfb5. htm(Accessed 05.10.2015)

2. Clementine, Rex (2011) "Part 8 'Shopping is for Sissies." The Island. January 12, 2011. (Accessed 05.10.2015)

3. Dictioary.Com. 2015. http://dictionary.reference.com/browse/

4. Encarta Dictionary (2015).

5. Ernest Hemingway (1929). A Farewell to Arms. Penguin Edition 1973.

6. Glossary of Cricket Terms, Cricket Terminology, Cricketing Terms, and Cricketing Terminology. http:// www.cricker.com/glossary/(Accessed 05.10.2015)

7. Gunawardene, Nalaka (2008). "Sir Arthur C Clarke - Our tour guide to the future."Business Today, May 2008. http://www.businesstoday.lk/article.php?article=1173\#sthash.aERCyTf0.dpuf (Accessed 05.10.2015)

8. Kitao, Kenji \& S. Kathleen Kitao (1997). "Selecting and Developing Teaching/Learning Materials." The Internet TESL Journal, Vol. IV, No. 4, April 1997. http://iteslj.org/ (Accessed 13.11.2015)

9. Kordić, Snježana (1991). "Konverzacijskeimplikature" [Conversation implicatures] (PDF). Suvremenaling vistika (in Serbo-Croatian) 17 (31-32): 89. ISSN 0586-0296. Archivedfrom the original on 2 September 2012. Retrieved 9 February 2015.

10. Leech, G.N. (1983) Pragmatics, discourse analysis, stylistics and "the celebrated letter", Prose Studies, 6:2, 142-157, DOI: $10.1080 / 01440358308586191$

11. Maitipe, Anura (2008). "Five top UNP MPs to Cross Over." Sunday Observer. November 11, 2007. (Accessed 05.10.2015)

12. Merriam-Webster Dictionary (2015).http://www.merriam-webster.com/dictionary/meander (Accessed 05.10.2015)

13. National Institute of Education, Sri Lanka (2015). Appreciation of English Literary Texts: G.C.E. (Ordinary Level) - Teacher's Resource Book. Maharagama: NIE.

14. Niemoller, Pastor Martin (1941). "First They Came." Holocaust Memorial Day Trust. http://hmd.org.uk/ resources/poetry/first-they-came-pastor-martin-niemoller (Accessed 05.10.2015)

15. The Telegraph. "David Miliband in Sri Lanka to broker peace deal." 29. 04. 2009. http://www.telegraph. co.uk/news/worldnews/asia/srilanka/5240939/David-Miliband-in-Sri-Lanka-to-broker-peace-deal.html (Accessed 29.10.2015)

16. Waraich, Omar (2009). Attack on Sri Lankan Cricket Team: Echoes of Mumbai? Time Inc. Mar. 03, 2009. http://content.time.com/time/world/article/0,8599,1882745,00.html(Accessed 05.10.2015)

Citation: Dr. Edirisingha Arachchige Gamini Fonseka, "A Pragmatic Study of "The Lahore Attack" by Sri Lankan Cricketer Kumar Sangakkara: A Parody of Sportsmanship under Servile Diplomacy" American Research Journal of English and Literature, vol 4, no. 1, 2018, pp. 1-10.

Copyright (C) 2018 Dr. Edirisingha Arachchige Gamini Fonseka, This is an open access article distributed under the Creative Commons Attribution License, which permits unrestricted use, distribution, and reproduction in any medium, provided the original work is properly cited. 